\title{
Student autonomy in doing the task and information service's
}

\author{
Nurhaidah Napitupulu ${ }^{1}$, Prayitno ${ }^{2}$, Marjohan ${ }^{3}$ \\ ${ }^{123}$ Universitas Negeri Padang, Padang - Indonesia, (nurhaidahnapitupulu@yahoo.co.id)
}

\begin{abstract}
Many students did not have autonomy in doing the task which teachers give. The research was aimed to describe the quality of students autonomy in doing the school tasks and the students opinion about the quality of information service implementation to improve student autonomy as the realization of the guidance and counseling services function. This research used quantitative method with descriptive statictics. The population were national and private junior high school which is on grade A in Padang City. The samples was 120 students. Data were analyzed by using statictics technique.The result shows that the quality of student autonomy in doing the task and the students opinion about the quality of information service by counselor to develop students autonomy in doing the school task was in high category, and the quality of student autonomy and the quality of the information service in the two school was in significant correlation.
\end{abstract}

Keywords: autonomy doing the task information service's

\section{Introduction}

The success of learning was not only determined by the ability of educators who were required to teach professionally with good methods and curriculum, but also the active role of students in the learning process. The importance of doing the tasks of teachers relates to the effort to improve understanding and mastery of the subject matter well. Mudjiran (2015:51) argues that "Structured assignment was expected to encourage students to be more active in learning, while providing an opportunity to initiate independently according to their potential and talents of interest.

This the task of the school given the subject teacher aims to build the initiative and creative students. The task was given so that students can exercise a sense of responsibility by completing their school work. Students were encouraged to have a sense of responsibility for completing their schoolwork.

Roestiyah (2012) mentions that the technique of assignment or recitation was usually used with the aim that students have a more stable learning outcomes, because students carry out exercises during the task. From that process, students in learning lessons can better understand the effects of different experiences and experiences of students in the face of new problems or situations.

Independence was a personal condition capable of developing the basic human potential for the upholding of human nature to itself in the frame of human dimension (Prayitno, 2009). It could be 
concluded that anyone who was able to develop the basic human potential on himself then they were independent individuals. The characteristics of independence were: (1) understand and accept oneself objectively, positively and dynamically, (2) understand and accept yourself and the environment objectively, positively and dynamically, (3) able to make decisions, (4) able to make decisions (3) selfdirected, and (5) manifesting oneself. Gea (2003) in his research argued that a student was said to have independence if he has been able to perform its tasks independently without relying on others.

Student independence needs attention, by counselor to providing services to students about activities they could do independently, especially when they were doing school work to effort service by couselor in training the independence of students should be supported and assisted by subject teachers and parents. This opinion was reinforced by Prayitno (2000) who suggests that one of the determinants of student success in learning was the extent to which they could complete the tasks required by subject teachers.

Working on the tasks assigned by subject teachers requires strong motivation to do the tasks. Motivation that leads to independence becomes important because independence causes persistence, tenacity and perseverance in doing the task.

Information service was considered appropriate to be used in an effort to improve student independence in doing school work, because with the information service by counselor in particular can provide information and assistance to students about the importance for students to do school work. Information services intended to achieve the goal was to utilize classical dynamics to achieve a goal, where the topics and methods are poured through various student learning experiences in the classroom.

Taking note of the above matters the authors conducted a preliminary study at an accredited State A Junior High School and Private School in Kota Padang, the result shows that there are still many students who did not have independence in doing school work. his could be seen from the number of results of student tasks that were not satisfactory, late in collecting tasks, and assigned tasks created with the results cheat. In group assignments they do not work well together, just rely on one group member to do it.

Based on the existing symptoms, it could be understood that, students in National Junior High School and Private School in Kota Padang, many who did not have independence in doing tasks given by teachers at school.

\section{Method}

This research used descriptive quantitative method, with population of National Junior High School and Private School A accredited in Padang City, whose sample was determined by purposive random sampling technique. Data were collected using questionnaires autonomy in doing the task and the students opinion about the quality of information service by counselor to develop students autonomy in doing the school task, the results were analyzed using statistical techniques.

\section{Results and Discussion}

Data in this research included variable of student independence in doing school task, and information service by counselor. Results of data analysis of quality research students in doing school work on two State Junior High Schools and Private in the City of Padang in Table 1 and Graph 1 following. 
Table 1. Student Autonomy in Doing The Task

\begin{tabular}{llccccccc}
\hline No & Quality Category & Score Range & \multicolumn{2}{c}{$\begin{array}{c}\text { National } \\
\text { Junior High } \\
\text { School }\end{array}$} & $\begin{array}{c}\text { Private Junior } \\
\text { High School }\end{array}$ & \multicolumn{2}{c}{ Total } \\
\cline { 3 - 9 } & & & F & $\%$ & $\mathrm{f}$ & $\%$ & $\mathrm{~F}$ & $\%$ \\
$\mathbf{1}$ & Very Good & $113-125$ & 27 & 45 & 19 & 31,67 & 46 & 38,33 \\
$\mathbf{2}$ & Good & $100-112$ & 13 & 21,67 & 14 & 23,33 & 27 & 22,5 \\
$\mathbf{3}$ & Enough & $81-99$ & 15 & 25 & 21 & 35 & 36 & 30 \\
$\mathbf{4}$ & Less & $69-80$ & 5 & 8,33 & 5 & 8,33 & 10 & 8,33 \\
$\mathbf{5}$ & Less Once & $\leq 68$ & - & - & 1 & 1,67 & 1 & 0,83 \\
& & & 60 & 100 & 60 & 100 & 120 & 100 \\
\hline
\end{tabular}

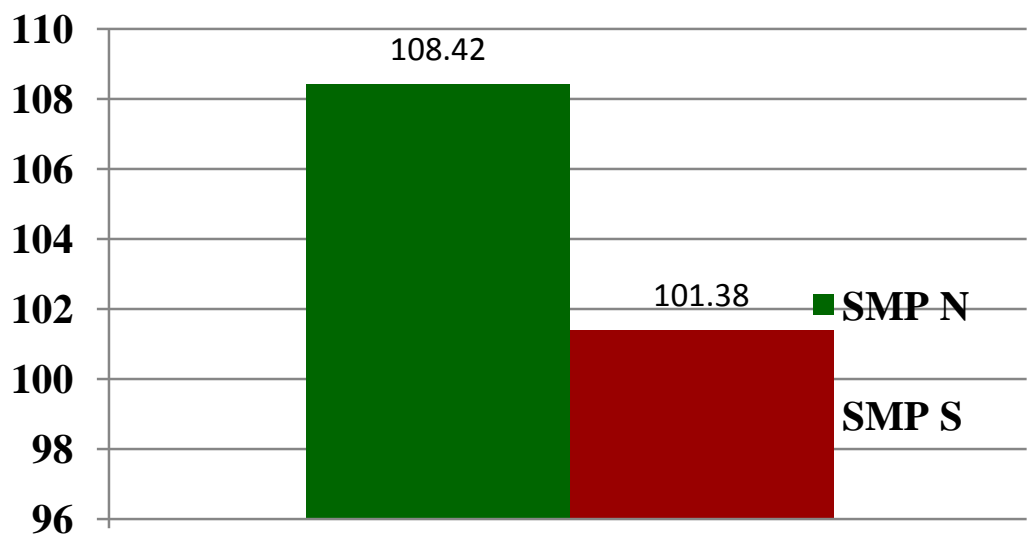

The Quality of Student Autonomy in Doing The School Task

Graph 1

Overall the quality of student independence in doing school work was in good category position with average score $104,9(83,61 \%)$. The average score of quality at Private Junior High is lower than National Junior High School, with significant difference.

The result of data analysis of the student opinion about the quality of information service by counselor to develop student's autonomy in doing the shool task of national junior hight school and private junior hight school which is on grade A in Padang City in Table 2 and Graph 2 following. 
Table 2. The Sudent's Opinion About The Quality of Information Service

\begin{tabular}{|c|c|c|c|c|c|c|c|c|}
\hline \multirow[t]{2}{*}{ No } & \multirow[t]{2}{*}{ Quality Category } & \multirow[t]{2}{*}{ Score Range } & \multicolumn{2}{|c|}{$\begin{array}{c}\text { National } \\
\text { Junior High } \\
\text { School }\end{array}$} & \multicolumn{2}{|c|}{$\begin{array}{l}\text { Private } \\
\text { Junior } \\
\text { High } \\
\text { School }\end{array}$} & \multicolumn{2}{|c|}{ Total } \\
\hline & & & $\mathrm{F}$ & $\%$ & $\mathrm{~F}$ & $\%$ & $\mathrm{~F}$ & $\%$ \\
\hline 1 & Very Good & $113-125$ & 28 & $\begin{array}{c}46,6 \\
7\end{array}$ & $\begin{array}{l}2 \\
6\end{array}$ & $\begin{array}{c}43,3 \\
3\end{array}$ & 54 & 45 \\
\hline 2 & Good & $100-112$ & 5 & 8,33 & $\begin{array}{l}2 \\
2\end{array}$ & $\begin{array}{c}36,6 \\
7\end{array}$ & 27 & 22,5 \\
\hline 3 & Enough & $81-99$ & 23 & $\begin{array}{c}38,3 \\
3\end{array}$ & 9 & 15 & 32 & $\begin{array}{c}26,6 \\
7\end{array}$ \\
\hline 4 & Less & $69-80$ & 3 & 5 & 2 & 3,33 & 5 & 4,17 \\
\hline 5 & Less Once & $\leq 68$ & $\begin{array}{c}1 \\
60\end{array}$ & $\begin{array}{l}1,67 \\
100\end{array}$ & $\begin{array}{l}1 \\
6 \\
0\end{array}$ & $\begin{array}{l}1,67 \\
100\end{array}$ & $\begin{array}{c}2 \\
120\end{array}$ & $\begin{array}{l}1,67 \\
100\end{array}$ \\
\hline
\end{tabular}

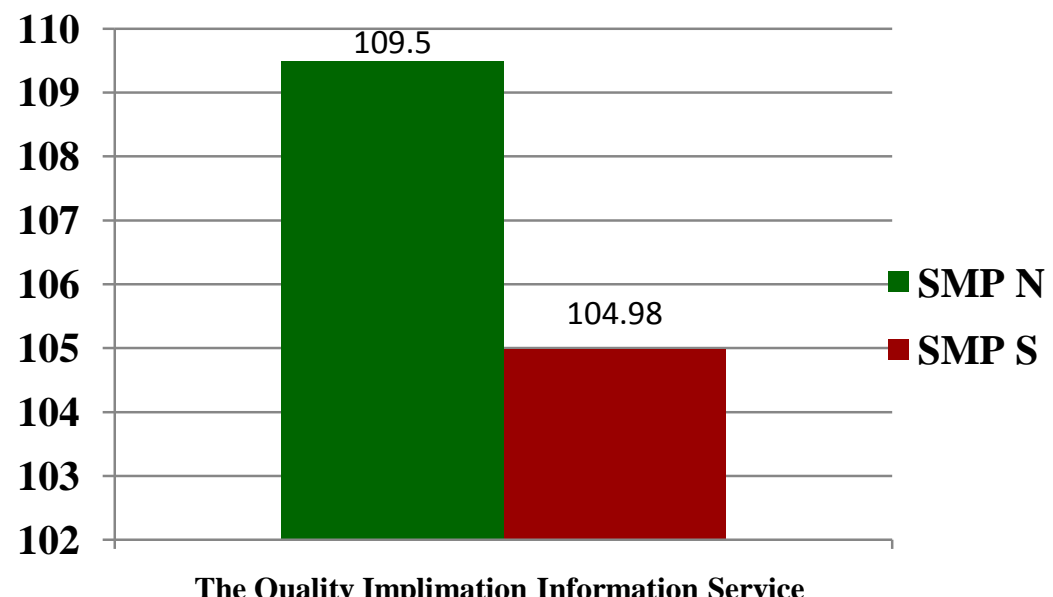

Graph 2

The student' opinion about the quality of information service by counselor to develop student's autonomy in doing the school task totality was ini high category, $107,24(85,795 \%)$. which the national junior high school student was higher than the state junior high school student.

The quality of student independence in doing school work and the quality of information services at national junior high school there was a significant relationship In private junior high school there was also a significant relationship between the quality of student independence in doing school work with the quality of information services.

The results showed that the overall quality of student stubbornness in doing school work on National Junior High Schools and Private students in the city of Padang accredited A was in a good category position with the level of respondents $83,61 \%$, with details $(38,33 \%)$, very good category, $(22,5 \%)$ were in good category $(8,33 \%)$ were in the less category $(0,833 \%)$, were in less once. 
Students at National Junior High Schools and Private students in the city of Padang accredited A were known through the research data that as stated tertera $83,61 \%$ has had the independence in functioning well. Based on the most prominent school work instrument material that was about:

1. Five items with the highest score: (1) I was ready each time and willingly accept the assignment given by the teacher. (2) I chose the right way to complete my schoolwork to get a good grade. (3) I did my best to earnestly complete the task as well as possible. (4) I could hardly really understand the task given by the teacher as well as possible. (5) I chose the right learning resource for doing school work.

2. Five items the lowest score: (1) I tried earnestly to follow up the task returned by the teacher. (1) I sincerely understand the state of the environment in relation to the school work. (1) I used the things in the environment to fully utilize to complete the schoolwork. (1) Under my circumstances I try to turn in my duties on time. (1) Under circumstances the environment may somehow improve the task returned by the teacher.

3. Another thing that needs to get attention, namely the students of national junior high school, significantly the quality of independence in doing the task was higher than the Private Junior High, this means there was a difference in the quality of independence of students in doing school work on Junior High School students and Private Junior High School.

Student independence had an important role in performing the task, the role of independence was seen in the way of thinking, how to work and how to act in doing school work that had a positive impact on the progress of learning and become an effort in improving student achievement. Surya (2011) explained the self-reliant habit will encourage persistence, tenacity, fortitude, way of thinking, how to work and how to act oriented in a progress.

The results showed that the students opinions about the quality of the implementation of information services by the Counselor in developing the independence of students doing school work was in good category position with the level of respondents $85,795 \%$, with details $45 \%$ students were in very good category $22,5 \%$ students were in good category $26,67 \%$ students were in enough category $41,7 \%$ students were in the less category in $1,67 \%$ students were in the category less once.

The results of the study pertaining to the implementation of information services of counselor who realize information services in school work assignments show that by counselor at school has performed its responsibilities well by counselor it is hoped that the service materials will be tailored to the needs of students doing school work. Mirnayenti, Syahniar \& Alizamar (2017) revealed that information services work to develop students themselves with regard to student attitudes and habits.

Implementation of information services by counselor service in State and Private Junior High School differs in developing students' independence in doing basic schoolwork in helping to understand the importance of independence in doing schoolwork. Students who know the importance of assignment from teachers will be more skilled in task completion activities (Budiardjo, 2008). The independence of students in doing school work can be more focused by knowing the basic understanding of independence in doing school work through the implementation of information services by counselor in developing student independence in doing school work.

Based on the results of data analysis obtained, indicating that there was a relationship of quality independence of students in doing school work with quality information services at National Junior High Schools and Private students in the city of Padang accredited A there were a positive and significant relationship. Judging from the category of quality of student independence in doing school work and quality of information services that have a reciprocal relationship. The counselor in 
addition to being required to understand the needs of students and develop student independence in doing school work also need to carry out information services with appropriate procedures. In the case of self-reliance development, students' understanding and mastery of the information services provided will enable students to understand and accept themselves and the environment objectively and dynamically, make decisions, direct themselves to useful activities in accordance with the decisions taken and finally self-actualization integrated. Those, if the mastery of information is really high quality, it was not impossible that the information can be used for broader student needs, (Prayitno, 2017).

\section{Conclusions}

The results of this research and discussion of student independence in doing school work and information services, could be summarized as follows:

Quality of student independence in doing school work in two and National Junior High Schools and Private students in the city of Padang accredited A being in the category of good average. The quality of students in Junior High School was higher than that of Private Junior High School significantly.

Quality of implementation of information services by counselor $n$ developing the independence of students doing schoolwork in two junior high school is in good category. The quality of junior high school students is slightly lower than that of SMP Negeri, but the difference is not significant.

Correlation between student independence in doing school work and quality of information service by counselor in developing the independence of students in junior high and high category.

\section{Acknowledgments}

Acknowledge anyone who has helped you with the study, including: Researchers who supplied materials, reagents, or computer programs; anyone who helped with the writing, or offered critical comments about the content, or anyone who provided technical help.

State why people have been acknowledged and ask their permission. Acknowledge sources of funding, including any grant or reference numbers. Please avoid apologize for doing a poor job of presenting the manuscript.

\section{References}

Budiarjo, M. (2008). Dasar-dasar Ilmu Politik. Jakarta: Gramedia Pustaka Utama.

Gea, A. A. (2002). Relasi dengan Diri Sendiri. Jakarta: Elex Media Komputindo.

Mirnayenti, M., Syahniar, S., \& Alizamar, 2017. “Efektivitas Layanan Informasi Menggunakan Media Animasi Meningkatkan Sikap Anti Bullying Peserta Didik". Insight: Jurnal Bimbingan dan Konseling, 6(2): 176-184.

Mudjiran. (2015). Pengembangan Model Penugasan Terstruktur Kepada Siswa, Padang: Sukabina Press.

Prayitno. (2002). Tim Program Semi-Que IV, Seri Latihan Keterampilan Belajar, Dikti/PPMPT/Depdiknas.

Prayitno. (2009). Wawasan Profesional Konseling. Padang: Universitas Negeri Padang.

Prayitno, (2017). Konseling Profesional yang Berhasil. Jakarta: Rineka Cipta.

Rostiyah N. K. (2012). Strategi Belajar Mengajar. Jakarta: Rineka Cipta.

Surya, H. (2011). Strategi Jitu Mencapai Kesuksesan Belajar. Jakarta: Gramedia. 